Shells," facing p. I4, it will be seen that in place of this species the author has actually had figured the marine shell commonly known as Pileopsis hungaricus. Nor is this all, for in the same plate an Ampullaria does duty for Paludina (or Vivipara); while instead of the freshwater Thames Neritina we have the marine West Indian Neritina radiata depicted. Comment is superfluous!

Neither is Mr. Cornish less unfortunate when, in the chapter on "London's Buried Elephants," he essays to enlighten his readers on the fauna of the Thames valley in Pleistocene times. Passing over his misuse of the term "Prehistoric" as equivalent to "Pleistocene," which in a work of this nature may be regarded as a venial sin, we find on p. 234 , in connection with the discovery of mammalian remains during the excavations for the foundations of the Victoria and Albert Museum at South Kensington, the following sentence :-

"So on the London 'veldt' there were lions, wild horses (perhaps striped like zebras), three kinds of

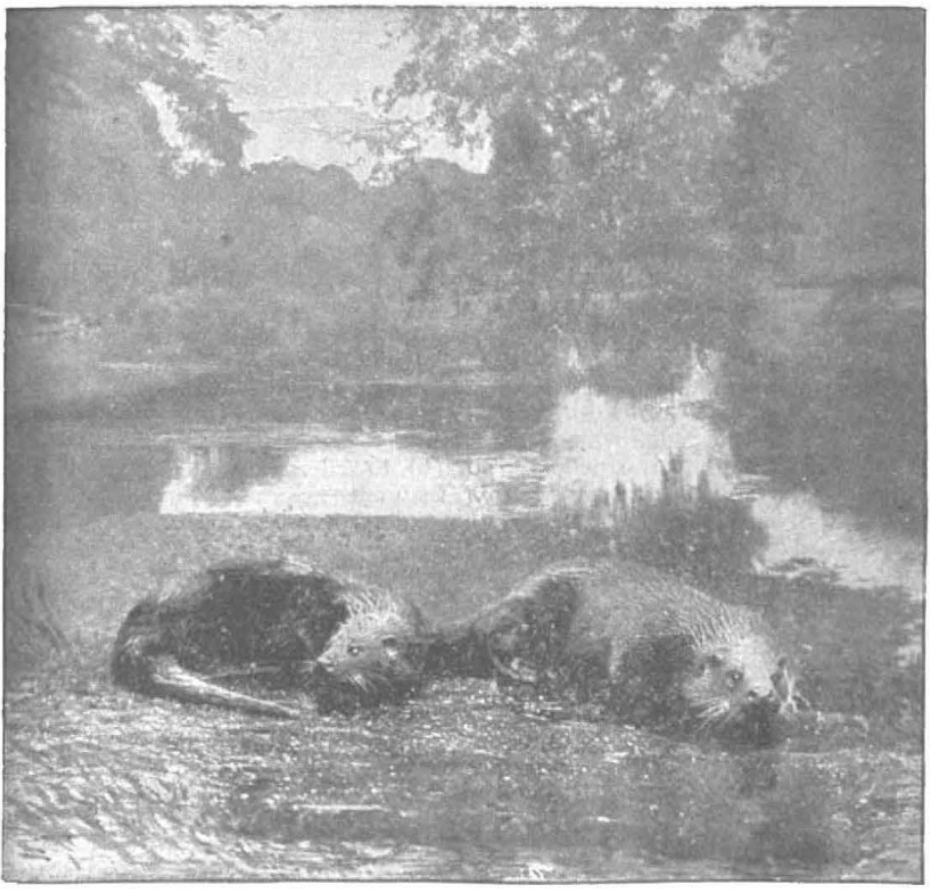

Frg. x.-Otters.

rhinoceroses-two of which were just like the common black rhinoceros of Africa, though one had a woolly coat-elephants, hyanas, hippopotami, and that most typical African animal, the Cape wild dog !"

The author may well place a note of admiration at the end of this sentence, for it is in truth a most remarkable one. To begin with, Mr. Cornish is apparently unaware that the domesticated horse, with which the Pleistocene race agrees in every particular as regards its skeleton, differs remarkably from the asses and zeloras in regard to the proportionate size of the front and hind hoofs; and from this essential difference we are entitled to argue that even in Pleistocene times it was most certainly not striped, such striping as occurs on the legs of certain domesticated horses being probably due to a cross. A certain degree of obscurity veils the part of the sentence referring to the Thames rhinoceroses, but it may be confidently stated that neither was exactly like the living African black species, while the woolly-coated kind was a relative of the living white rhinoceros! But the most astounding statement is the one relating to the occurrence of the Cape wild, or hunting, dog in the Thames valley deposits. It is true, indeed, that the present writer has ventured to refer, provisionally, a single lower jaw from a cave in Glamorgan to the same genus as the animal in question, but that appears to be the only evidence of the former existence in Britain of any representative of the genus Lycaon; and we are informed by Mr. Cornish that the Cape species once lived in London!

But this is not all, for on p. 235 we find it stated that among the London Pleistocene fauna are included "the pika, a little steppe hare, and an extremely odd antelope now found in Thibet. This is a singularly ugly beast with a high Roman nose, and a wool almost as thick as that of a sheep when the winter coat is on. It must have been quite common in these parts, for I have had two of their horns brought to me during the last few years."

From the second sentence in this quotation it is quite clear that by the "extremely odd antelope" the author means the saiga. That aninal, however, is not an inhabitant of 'Tibet, where it is represented by its distant cousin the chiru, with which it has evidently been confounded by the author. With reference to the statement that it was formerly common in the Thames valley, we venture to differ from the author. A frontlet has been obtained at 'Twickenham, and we believe one or two other specimens are known from British deposits, but these are all that have come under the observation of persons competent to decide the affinities of animals represented by fossil bones.

If the two chapters we have been compelled to criticise thus severely have been before the public previously, the repetition of such absurd mis-statements is the more unpardonable.

In his proper sphere Mr. Cornish is an entertaining and pleasant writer, and it is therefore the greater pity that he is so illadvised as to attempt subjects of which he has no practical knowledge.

R. L.

\section{MR. BALFOUR ON TECHNICAL EDUCATION AT MANCHESTER} $\mathrm{A}^{S}$ announced in these columns last new Manchester School of Technology on Wednesday, October i 5. For many year past, the provisions for technical education in the city of Manchester have been remarkable for their excellence, and an ac. count of the successful efforts made by the Technical Instruction Committee of the City Council, the School Board and other educational authorities to educate Manchester citizens was given in an article published in our issue for January 3I, 1901. One cause among many of the high state of development of education in Manchester is the broad view of its duties taken by the Technical Instruction Committee. On several occasions the Committee has arranged for the present principal of the school, Mr. J. H. Reynolds, to visit foreign countries to study other systems of technical instruction. In this way the Manchester educational authorities have become practically acquainted with German and American methods of education, and though they have not slavishly followed these ideas in organising their new school, they have not hesitated to adopt ideas they consider suitable for the peculiar needs of their own district. For the following extracts from Mr. Balfour's speech at the opening of the new school we are indebted to the 7 ïmes.

NO. I72 I, VOL. 66] 
Mr. Balfour said he counted it a most happy and fortunate circumstance that he had been able to take any part whatsoever in an occasion which was interesting, not merely to Manchester or merely to Lancashire, but to the whole of a country which depended in an ever-increasing degree upon its power to preserve its position as a great manufacturing centre. The building was perhaps the greatest fruit of that kind of municipal enterprise in this country, and though he would be presumptunus in saying that the brief visit he had been able to pay to it had given him: any adlequate or sufficient idea of all that it was capable of doing for the industries of I,ancashire, still nobody could go over the building, observe its equipment, study even in the most cursoly manner the care which had been devoted to it, without feeling that the corporation had set a great example worthy of the place it held in Lancashire and in Great Britain.

The great building in which they were assembled was an outward and visible sign of that awakening which had come over our people in view of the ever-changing conditions of intellectual industry. There was a time when we could flatter ourselves without any undue egotisn or vanity that not only were we the first of the industrial nations, but that the rest were nowhere. That time had passed never to return again, and he was far from uttering selfish complaints at that change in the condition of the world which was absolutely inevitable, and from which they ought not to be, and in his judgment would not be, the ultimate losers. It was a profound mistake to suppose that the fact that other nations were now great producing centres was an injury pure and simple to this country. It was nothing of the kind. The growth of the wealth of the world must be a benefit to every part of the world, and all that we had to do was to see that we bore our full share in the great industrial development.

But not only was there the change in the industrial condition of the world to which he had adverted, but another change had occurred more closely connected, perhaps, with the necessity $f(r)$ institutions of this character. It was the change from the prescientific to the scientific stage of industry. When England or Great Britain first obtained its great manufacturing monopoly, it was not too much to say that the relation between science and industry was of the feeblest character. There was always, of course, the closest connection bet ween mechanical ingenuity and invention and the great growth of our industries, but the in. timate correlation between the discoveries of the laboratory and the processes of the workshop was not in existence, and it was because we had been a little slow to discover in this country how intimately speculative research is connected with manufacturing progress that we were, in some branches of our work at all events, behind our neighbours, who in this respect, although not in many others, had proved themselves more ready and more apt to learn that lesson, than we had ourselves. And if anybody wanted a proof of the truth of the proposition he w.1s laying down they had only to recall the kind of meaning which the average man attached only a few years ago to the phrase "technical instruction." In the phrase "technical instruction" there was, in the minds of the people of whom he spoke, no scientific tinge or flavour whatever, but some kind of knowledge of manual dexterity, some opportunity for learning the uses of machinery, and so forth. But the fact on which he was venturing to insist, and on which the very existence and justification of an institution like that at Manchester depended, was that henceforth and evermore there would be a closer and closer connection between the most remote and abstract scientific study of the chemist, of the physicist, of the electrician in his labor atory, and the great industries of the community of which he was a member. II wished he could be quite sure that even now, and even in the more cultivated part of the community, there was a more perfect appreciation of two capital facts which he would like to impress upon all who heard him. One was that education was, and must be, an organic whole, and that it was perfectly vain to spend vast sums upon buildings and equipments unless the student who went to those places went adequately prepared to learn the Iesson they could teach. He had not the slightest intention of over-exalting or over-praising foreign nations at the expense of our own, but it must be admitted that they had grasped much more fully and much more firmly the great truth on which he was insisting-namely, that a man rally to profit by the scientific training which he could get in these institutions and to be able himself to turn the learning he acquired to the purpose of original discovery, it may be of original research of his own, had to go there, not a raw product, but at all events a half-prepared human product. He should go here, no: only anxious to learn, but ready to learn.

Another great truth was that, after all, the persons who were responsible for the manufactures of the country were the manufacturers. It was perfectly vain and useless to turn out highly. trained and capable servants if there were not to be employers for them when they were turned out. He did not in the least know whether in Germany, for instance, they might not have overdone the matter; he had not sufficient evidence on the point, but he was quite sure something must be very wrong when he saw the extraordinary difference in the practice of the great German and in some, at all events, of the English firms. He was speaking on a subject which he only knew at second hand to people who knew the whole thing at first hand; but, unless his information greatly erred, they would find, if they went to Germany, at all events a few years ago, and studied the cquipment of one of the great German industrial concerns, electrical, chemical, optical or what not, a proportion of scientifically trained students in the German manufactory enormously in excess of anything commonly thought necessary in this country. There was not the least use in the Manchester Corporation turning out competent students if those students were not to find employment when they were turned out. With the naturally conservative instincts of our nation, the tradition of the great manufacturing establishments would rather tend to make people say that the best, the only place in which to learn was not in the lecture-room, but in the shop, not at the feet of skilled professors, Lut actually among the artisans who were carrying on the industry, and he did not deny there was a great deal of truth in that, and that probably we gained a great deal by our extreme anxiety to make industrial training a practical training. But he felt confident that they drove that truth too far, and that, however sound the instinct might be which lay at the bottom of it, they were working it too hard at the present time, and that, if they really did mean to turn the brains, and the muscles, and the enterprise, and the energy, and the in. ventive skill of their countrymen to its best purpose, it was absolutely necessary to place among the directors of industry those who had not merely that admirable and necessary practical knowledge which consisted in seeing things done from day to day by the people who had to sell the article when it was finished, but, in addition, they must give that complete scientific training which had become more the basis of our whole industrial fabric.

He did not deny that there might be dangers in that course. Every policy they adopted required watching ; every policy they adopted would petrify into some stupid and pedantic rules unless they kept close to the ever-varying realities of life, and if anybody said there might be a certain danger that they would have a quasi-scientific and industrial orthodoxy which would stand in the way of quick development in every new discovery in mechanics or in science, he did not deny that the danger night possibly exist. The way to meet it was to remember that true theory and true practice could never be divorced without loss to both, and that the ideal for which they had to strive was not that of simply imitating the processes of those who went before, but imitating their energy, their anxiety to take the best the world had to give - the world both of practice and of theoryin the changed and ever-changing conditions of our time. Let them imitate this great quality of their forefathers, and then institutions like that school would bear all the fruit of which they were capable. They would see the marriage of science and industry far more fertile and far more productive of good, and those who had called, and not called in vain, on Manchester for this great effort of municipal liberality might feel that their labours had not been thrown away, but that they had done great things for the growth, the maintenance and the expansion of those industries on which the health and existence of the community depended.

\section{NOTES.}

The office of Meteorological Reporter to the Government of India will become vacant in about a year by the retirement of Mr. J. Eliot, F.R.S., who has administered the office with great success for a long series of years. The selection of suitable names for consideration, with a view to the filling of the prospective vacancy after a preliminary period of training in Europe and in India, is now occupying the attention of an

No. I 72 I, VOL. 66] 